\title{
THE BEHAVIOUR OF NATIONS
}

\section{The Behaviour of Nations}

An Essay in the Conduct of National Organisms in the Nutritional Field. By Morley Roberts. Pp. $x i+180$. (London: J. M. Dent and Sons, Ltd., 1941.) 12s. $6 d$. net.

$\mathrm{T}$ HE author begins with an analogy that biological readers find difficult, namely, that between the State or nation and an organism. Its limitations concerning phases and duration of life, integration of component units, reproduction and external relations reduce its value. If, however, even a partial value be attached to the analogy, then the special parallel the author draws between the State and a low-grade organism becomes valuable, for there must be few who have not reflected that the greatest eommon measure of a large mass of humanity must be low ; and Machiavelli has told us this for centuries in his own grim fashion.

Morley Roberts sets forth for us here in all its nakedness, gaunt and unashamed, the Machiavellian doctrine that society is based on force, that groups of mankind inevitably compete for nutrition-by which he means supplies of all kinds-that phases without war are but interludes, usually preparatory to another struggle. To him, leaders are chiefly those who perceive and express the movements of their time for new or increased supplies. He does not know what is meant by international morality, and decries the romantic conceptions of the Churches and other idealists. This is accordingly a book for idealists to read if they still feel disposed to indulge in that form of escapism which devotes itself to making paper plans for a better world.

In the world as it is, occupation without effective power of defence against organized mechanism is not real possession. Holland, Belgium, Norway, Poland, Yugoslavia, Greece, Italy, even France, were not really the possessors of their territories; they were temporary holders until such time as the great mechanism should descend upon them. Paper treaties professing to give security to the weak are frail ; even worse, they are death-traps not seldom used by the great mechanism to gain time that it may do one job at a time, and that thoroughly.

Irritated national organisms which are equipped with mechanical power have not been amenable to moral reproof or to the diplomatic nursing that has come to be known as appeasement. Appease them by concession, and, at once, by the very principle of their being, they start scheming for more. Moral reproof, as in the pitiful case of Italy and Abyssinia in 1936, is equally futile, and still more irritating, a still greater excitant for the have-not organism which can obtain mechanical resources. Machiavelli told the Prince that he must either destroy or make a (subordinate) friend of his adversary ; intermediate policies are disastrous.

Morley Roberts thinks history is largely a record of social pathology; even some of the more optimistic of us will go as far as to say it tells us, in the main, what comes of choosing the second, often even the third best.

The book is full of challenging opinions. Norway, Holland, Belgium, France were really destroyed before a gun was fired. Nationalism is a dream that is fading, and men in each nation can be found to co-operate with the enemy and to accept his crusade for a unified Europe, based on what the author calls the tribe, wherein are no differentiations, no parties, for parties would mean differentiation. The collapsed nation States of the west and northwest had advanced dangerously far beyond this tribal stage, and they acted as hypnotized rabbits facing a giant stoat. Nothing that has happened in the last three years but could have been foretold by any German boy of reasonable intelligence between Passau and Heligoland as the inevitable line of action of eighty million claustrophobes, lured, as ever, by the open sea and the sunny south, and pressed on by the spectre of the Slav birth-rate. Long-range politics are in large measure a function of the birth-rate. The author is fond of Spinoza's statement that he wished to understand rather than to abuse a thunderstorm, and the publisher refers to the book's passionless analyses ; but, for all that, the fire burns fiercely under a biological cover.

There is another picture to be drawn. Units within which there is some legal restraint, some mutual aid, have grown from the days of huntercollector groups through those of village cultivators and of rival city States to, and now just beyond, those of tribes and nations. What next? Are we to witness rival giant powers, Atlantic or Anglo-American, European or Germanic, Russian or 'Heartland', in the sense of Mackinder's remarkable forecast in "Democratic Ideals and Reality", and Oriental ? Or can we try, by reducing divergences of standards of living, to achieve a world order with a backing of adequate strength ?

H. J. Flevre. 